\title{
Successful autotransfer of tubal eggs in the rhesus monkey (Macaca mulatta)
}

\author{
J. H. Marston, R. Penn and P. C. Sivelle \\ Department of Anatomy, Medical School, University of Birmingham, B15 2TJ, U.K.
}

To date there are only two reports of attempts to transfer embryos in or between individual primates (Steptoe \& Edwards, 1976; Kraemer, Moore \& Kramen, 1976). The purpose of this communication is to report the successful recovery and re-transfer of fertilized eggs in the rhesus monkey (Macaca mulatta).

Thirteen naturally mated rhesus monkeys were subjected to laparotomy on Days $12-18$ of the menstrual cycle and a fertilized egg was recovered from the oviducts of each (Marston, Kelly \& Eckstein, 1969a). The flushing medium and that used for manipulation was Dulbecco's complete phosphate-buffered saline maintained at room temperature $\left(20-24^{\circ} \mathrm{C}\right)$. The flushings were examined under a stereomicroscope and when the egg was located it was immediately taken up in a fine nylon i.v. cannula ( $0.63 \mathrm{~mm}$ o.d., Portex Ltd.). The cannula was attached to an Agla micrometer syringe filled with sterile liquid paraffin and was controlled by an assistant.

Individual eggs were returned to the contralateral oviduct or to the uterus of the donor monkey within 30 min of recovery: most transfers were effected within $15 \mathrm{~min}$. The technique for the uterine transfers has been described by Marston et al. (1969b). For the oviductal transfers the tip of the nylon cannula was introduced through the tubal ostium to the point at which there is usually a marked flexure of the ampulla. Each egg was expelled from the cannula in about $0.5 \mu$ medium with a similar volume of air.

The results of the transfers are summarized in Table 1 . The pregnancies were first detected at about 20 days after transfer by the occurrence of 'implantation bleeding' and a positive N.I.H. Sub-Human

Table 1. Summary of 13 experiments in which a fertilized egg recovered from the oviduct of a rhesus monkey was placed in the contralateral oviduct or uterus of the same animal

\begin{tabular}{|c|c|c|c|}
\hline Stage of egg development & No. of eggs & $\begin{array}{l}\text { No. of } \\
\text { pregnancies }\end{array}$ & Comments \\
\hline \multicolumn{4}{|l|}{ Transfer to oviduct } \\
\hline $\begin{array}{l}\text { 1-Cell (with 1st and 2nd polar bodies) } \\
\text { 2-Cell }\end{array}$ & 2 & 2 & At 30 and $40^{*}$ days of gestation \\
\hline Intact & 2 & 2 & At $135 \dagger$ and $145 \dagger$ days of gestation \\
\hline One blastomere ruptured & 1 & 1 & At $155 \ddagger$ days of gestation \\
\hline 4-Cell & 2 & 1 & At 100 days of gestation \\
\hline 6-Cell & 2 & 2 & $\begin{array}{l}\text { Male baby born } 15 \text { November } 1975 \\
\text { Now at } 140 \dagger \text { days of gestation }\end{array}$ \\
\hline Morula ( 22 cells) & 1 & 0 & \\
\hline \multicolumn{4}{|l|}{ Transfer to uterus } \\
\hline 5-Cell & 1 & 0 & $\begin{array}{l}\text { Negative N.I.H. Pregnancy Test } \\
\text { but a long 'implantation-type' } \\
\text { bleeding }\end{array}$ \\
\hline 7-8-Cell & 2 & 0 & $\begin{array}{l}\text { Positive N.I.H. Pregnancy Test } \\
\text { obtained from one female }\end{array}$ \\
\hline
\end{tabular}

* This female gave birth to the first egg-transfer baby.

$\uparrow$ See note added in proof.

$\ddagger$ See note added in proof. 
Primate Pregnancy Test reaction. The animals were anaesthetized and handled for the first time after transfer at about 30 days, when the pregnancy was confirmed by rectal palpation of the uterus and cervix. Pregnant animals were regularly X-rayed from about Day 90 of gestation.

The male baby born in November 1975 is fit and well: its development and gross appearance seem to be normal. The current pregnancies appear to be progressing normally and radiography shows that the fetuses have normal skeletal development. Early and undetected abortion could have occurred in the 2 animals which showed one positive sign of early conception.

The success of the present experiments confirms that the techniques employed have not affected adversely either the eggs or the conditions for conception. The results also prove that the environment provided by the contralateral oviduct, away from the immediate influence of the corpus luteum, is adequate for the survival of the embryo. Uterine transfer of the egg can be used to mimic the conditions of accelerated tubal transport, and in the present experiments it seems likely that the eggs were placed in the uterus at least 1 day ahead of their normal schedule. It may be significant that 2 of the 3 animals receiving uterine transfers each showed one positive sign of early conception. Our results suggest that perfectly synchronized transfers of tubal eggs between rhesus monkeys should have a good chance of being successful. Kraemer et al. (1976) obtained one pregnancy in their series of 10 synchronized, between-animal transfers of uterine eggs in the baboon (Papio cynocephalus) using techniques similar to ours. Their results may reflect the greater technical difficulty of making uterine transfers, but are perhaps more likely to be due to the difficulties of synchronizing the donor and recipient animals. It may therefore be equally difficult to obtain successful heterologous tubal transfers in the rhesus monkey.

This work forms part of a W.H.O. Project (75034). We thank Mr H. Smith, Mr F. James, Mr G. Tonks and Mr R. Bryson for their care of the monkeys and Ms S. Greenwood for technical assistance.

\section{References}

Kraemer, D.C., Moore, G.T. \& Kramen, M.A. (1976) Baboon infant produced by embryo transfer. Science, N.Y. 192, 1246-1247.

Marston, J.H., Kelly, W.A. \& Eckstein, P. (1969a) Effect of an intra-uterine device on gamete transport and fertilization in the rhesus monkey. $J$. Reprod. Fert. 19, 149-156.
Marston, J.H., Kelly, W.A. \& Eckstern, P. (1969b) Effect of an intra-uterine device on uterine motility in the rhesus monkey. J. Reprod. Fert. 19, 321330.

StePtoe, P.C. \& EDWARds, R.G. (1976) Re-implantation of a human embryo with subsequent tubal pregnancy. Lancet i, 880-882.

Received 13 August 1976

Note added in proof

Three females ( $\dagger$ ) have given birth to apparently healthy, live female babies. One female ( $\ddagger$ ) has produced a stillborn, but apparently normal male infant. 